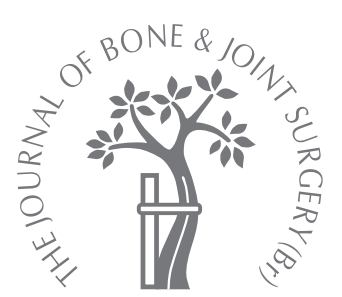

M. Ramachandran,

K. Lau,

D. H. A. Jones

From Great Ormond

Street Hospital for

Children, London, England

\footnotetext{
M. Ramachandran

FRCS(Orth), Specialist

Registrar

K. Lau, PhD, Senior House Officer

D. H. A. Jones, FRCS, FRCS

Ed(Orth), Consultant

Paediatric Orthopaedic

Surgeon

Orthopaedic Department

Great Ormond Street

Hospital for Children,

London WC1N 3JH, UK.

Correspondence should be sent to Mr M. Ramachandran at 5A Wallace Road, Canonbury, Islington,

London N1 2PG, UK; e-mail:

manoj@krigroup.com
}

(C)2005 British Editorial

Society of Bone and

Joint Surgery

doi:10.1302/0301-620X.87B10.

$16445 \$ 2.00$

$J$ Bone Joint Surg $[\mathrm{Br}]$

2005;87-B:1406-10.

Received 26 February 2005;

Accepted after revision

2 June 2005

\title{
Rotational osteotomies for congenital radioulnar synostosis
}

In five children, six forearms with a fixed pronation deformity secondary to congenital radioulnar synostosis were treated by a derotation osteotomy of the distal radius and the midshaft of the ulna.

There were three boys and two girls with a mean age of 4.9 years (3.5 to 8.25) who were followed up for a mean of 29 months (18 to 43 ). The position of the forearm was improved from a mean pronation deformity of $68^{\circ}\left(40^{\circ}\right.$ to $\left.80^{\circ}\right)$ to a pre-planned position of $10^{\circ}$ of supination in all cases. Bony union was achieved by 6.3 weeks with no loss of correction. There was one major complication involving a distal radial osteotomy which required exploration for a possible compartment syndrome.

Congenital radioulnar synostosis is a rare anomaly when failure of segmentation of the radius and ulna results in a fixed position of the forearm ranging from neutral rotation to severe pronation. ${ }^{1,2}$ When the deformity is mild, little disability is evident, as the ipsilateral shoulder and wrist can compensate effectively, ${ }^{2,3}$ but with significant pronation the activities of daily living, including dressing, eating, washing and accepting objects in the palm of the hand, can be severely impaired. ${ }^{2,4,5}$

Attempts at resection of the synostosis in order to restore rotation of the forearm have, on the whole, been unsatisfactory, due to loss of correction and vascular compromise following extensive soft-tissue release and derotation. ${ }^{4,6,7}$ More recently, osteotomies distal to the site of the synostosis which fix the forearm in a functional position have been advocated. ${ }^{8}$ As derotation then takes place over a larger area, this procedure theoretically reduces the risk of secondary loss of correction and vascular complications. $5,8,9$

We describe the surgical technique, results and complications of rotational osteotomies of the forearm with wire stabilisation of the ulna.

\section{Patients and Methods}

Five children with congenital proximal radioulnar synostosis were treated by the senior author (DHAJ) using rotational osteotomies of the radius and ulna with stabilisation of the ulna by an Ilizarov wire. The clinical details of the patients are shown in Table I.
There were three boys and two girls with a mean age of 4.9 years ( 3.5 to 8.5 ). They were followed up for a mean of 29 months (18 to 43). All were right handed. The mean preoperative pronation deformity was $68^{\circ}\left(40^{\circ}\right.$ to $\left.80^{\circ}\right)$. It was measured with the patient's elbow held fixed to the side of the chest, the forearm at $90^{\circ}$ and a line through the styloid processes of the radius and ulna used in conjunction with a goniometer, as described by Ogino and Hikino. ${ }^{3}$ The left forearm was involved in two patients and the right in one. There was bilateral involvement in two.

One child (case 2 aged 4 years at operation) had staged bilateral procedures due to severe functional limitation secondary to bilateral fixed pronation of $80^{\circ}$. The patient with bilateral involvement (case 1) was aged 8 years 3 months at operation. The fixed pronation was less severe $\left(40^{\circ}\right.$ bilaterally) and functional limitation was only present in his non-dominant forearm.

Five forearms were classified as type III according to Cleary and Omer, ${ }^{2}$ with visible osseous synostosis associated with posterior dislocation of a hypoplastic radial head. One was of type II, with visible osseous synostosis and a normal reduced radial head. Case 1 had an associated duplication of chromosome 14 . Case $3 \mathrm{had}$ associated ipsilateral bowing of the radial shaft.

Operative technique. The patient is supine under general anaesthesia, with a well-padded tourniquet. The ulnar osteotomy is carried out in the midshaft using an oscillating saw via a 
Table I. Details of patients

\begin{tabular}{|c|c|c|c|c|c|c|c|c|}
\hline $\begin{array}{l}\text { Patient } \\
\text { number }\end{array}$ & Gender & $\begin{array}{l}\text { Associated } \\
\text { syndromes }\end{array}$ & $\begin{array}{l}\text { Associated } \\
\text { skeletal } \\
\text { anomalies }\end{array}$ & $\begin{array}{l}\text { Age at } \\
\text { operation }\end{array}$ & Affected side & Dominance & $\begin{array}{l}\text { Pre-operative } \\
\text { position }\end{array}$ & $\begin{array}{l}\text { Indication for operation } \\
\text { (functional limitation as } \\
\text { reported by patient and/or } \\
\text { parents) }\end{array}$ \\
\hline 1 & $\mathrm{M}$ & $\begin{array}{l}\text { Duplication } \\
\text { anomaly } \\
\text { chromosome } 14\end{array}$ & None & $\begin{array}{l}8 \text { years } 3 \\
\text { months }\end{array}$ & $\begin{array}{l}\text { Bilateral (left } \\
\text { forearm operated } \\
\text { on) }\end{array}$ & Right-handed & $\begin{array}{l}\text { Fixed } 40^{\circ} \\
\text { pronation } \\
\text { both } \\
\text { forearms }\end{array}$ & $\begin{array}{l}\text { Left forearm - absent } \\
\text { supination, unable to catch } \\
\text { ball, accept coins and small } \\
\text { objects; unable to clean } \\
\text { perineal area for hygiene }\end{array}$ \\
\hline 2 & $\mathrm{~F}$ & None & None & 4 years & $\begin{array}{l}\text { Bilateral (staged } \\
\text { procedure) }\end{array}$ & Right-handed & $\begin{array}{l}\text { Fixed } 80^{\circ} \\
\text { pronation } \\
\text { both } \\
\text { forearms }\end{array}$ & $\begin{array}{l}\text { Both forearms - unable to } \\
\text { hold plates and cups, play } \\
\text { with toys, inability to accept } \\
\text { small objects, difficulty } \\
\text { dressing, difficult perineal } \\
\text { hygiene }\end{array}$ \\
\hline 3 & $\mathrm{M}$ & None & $\begin{array}{l}\text { Bowing } \\
\text { ipsilateral } \\
\text { radial shaft }\end{array}$ & $\begin{array}{l}4 \text { years } 9 \\
\text { months }\end{array}$ & Left & Right-handed & $\begin{array}{l}\text { Fixed } 80^{\circ} \\
\text { pronation }\end{array}$ & $\begin{array}{l}\text { Left forearm - inability to } \\
\text { accept small objects and } \\
\text { coins, unable to hold plates } \\
\text { and cups }\end{array}$ \\
\hline 4 & $M$ & None & None & $\begin{array}{l}3 \text { years } 6 \\
\text { months }\end{array}$ & Right & Right-handed & $\begin{array}{l}\text { Fixed } 60^{\circ} \\
\text { pronation }\end{array}$ & $\begin{array}{l}\text { Right forearm - inability to } \\
\text { hold cups and plates, } \\
\text { difficulty dressing }\end{array}$ \\
\hline 5 & $\mathrm{M}$ & None & None & $\begin{array}{l}3 \text { years } 11 \\
\text { months }\end{array}$ & Left & Right-handed & $\begin{array}{l}\text { Fixed } 70^{\circ} \\
\text { pronation }\end{array}$ & $\begin{array}{l}\text { Left forearm - difficulty } \\
\text { accepting coins, difficulty } \\
\text { dressing }\end{array}$ \\
\hline
\end{tabular}

subcutanenous subperiosteal posterior approach. A 1.8$\mathrm{mm}$ Ilizarov wire is passed retrogradely from the osteotomy to exit through the olecranon, and then antegradely across the osteotomy into the distal ulna. The radial osteotomy is undertaken at the distal diaphyseal-metaphyseal junction through a volar approach using an oscillating saw. The tourniquet is released and the forearm rotated to a position of $10^{\circ}$ of supination. In all cases, adequate rotation was achieved without difficulty and satisfactory circulation maintained. The deep fascia of the forearm is incised proximally and distally at the osteotomy sites to allow for expansion of the muscle bellies. The wounds are closed in layers, the Ilizarov wire is bent and left proud of the skin. An above-elbow plaster cast is applied with the elbow flexed to $90^{\circ}$ and the forearm in the corrected position. The limb is elevated post-operatively and the patient closely observed for neurovascular complications overnight. The cast is reinforced the next day and the patient discharged.

All patients were admitted three weeks after operation for removal of the wire under general anaesthesia and conversion to a below-elbow cast. A plain radiograph confirmed callus at the osteotomy sites and the patients were allowed to mobilise the elbow. They were reviewed after a further three weeks and if the radiographs showed bony union, the cast was removed. If healing was delayed, the cast was retained until union was achieved. The patients were followed up at six-monthly intervals, and the position of rotation of the forearm recorded.

\section{Results}

The mean correction achieved at surgery was $78^{\circ}\left(50^{\circ}\right.$ to $\left.90^{\circ}\right)$ to a final position of $10^{\circ}$ supination in all cases. Radiographic evidence of bony union was seen in five forearms at six weeks and in one at eight weeks. This delay in union was noted in the dominant right forearm in staged bilateral operations. The dominant right forearm was corrected first and the attempted use of the dominant limb for activities of daily living may have accounted for the increased time to union.

At latest follow-up there was no loss of correction in any patient. In one child (case 4), marked dorsal angulation of the radial osteotomy seen at six weeks remodelled to nearly normal by 18 months (Fig. 1). Flexion and extension of the elbow and movements of the wrist were unaffected by the operation. All patients showed marked functional improvement and they and their families were satisfied with the results.

There was one major complication requiring re-operation. In case 3, a haematoma at the site of the radial osteotomy caused symptoms of a compartment syndrome. This presented as failure to achieve control of pain on the first post-operative day and required prompt surgical exploration. The haematoma extended proximally deep to the flexors, compressing them forward against the deep fascia. Flexor digitorum superficialis was indented by the edge of the fascia. The deep fascia was incised, relieving the constriction. The muscle bellies of the flexors were healthy. After 48 hours the fasciotomy wound was granulating satisfactorily and was left to heal by secondary intention. During follow-up, no neurovascular effects were noted and the scar was cosmetically acceptable.

\section{Discussion}

According to Wilkie, ${ }^{6}$ the first case of congenital radioulnar synostosis was described in 1793 by Sandifort in Museum Anatomicus. It is a rare anomaly, with approximately 350 cases recorded in the literature. ${ }^{10}$ It is thought to be caused by a failure of longitudinal segmentation with persistence of the cartilaginous anlage between the radius and ulna during the seventh week of development. The 


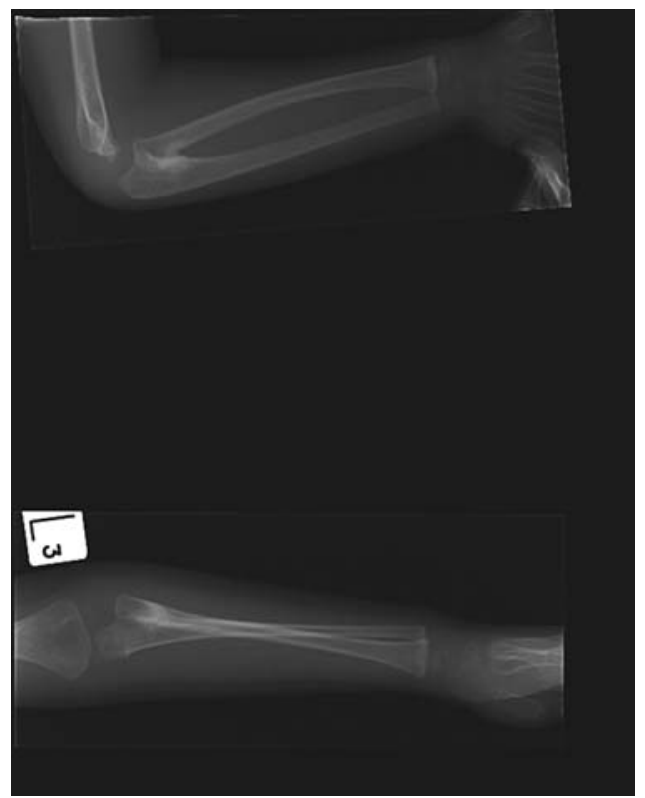

Fig. 1a

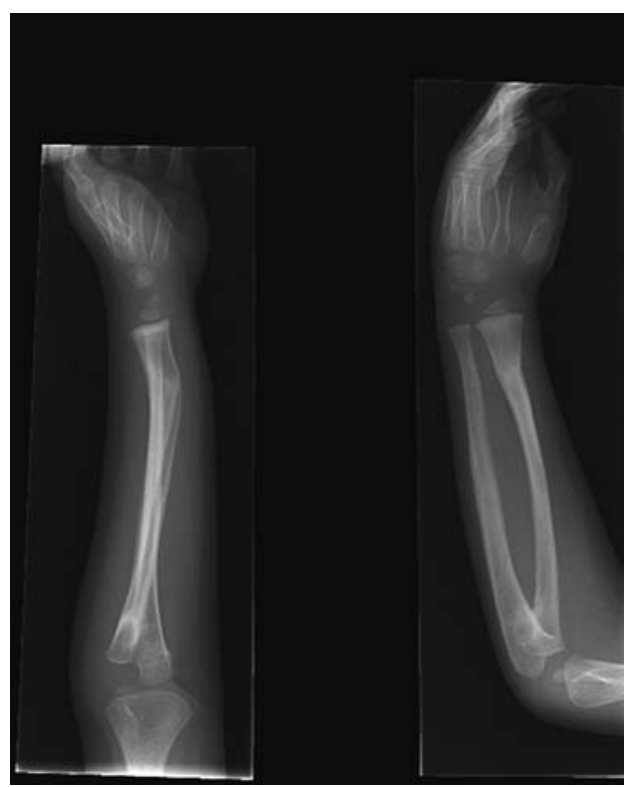

Fig. 1c

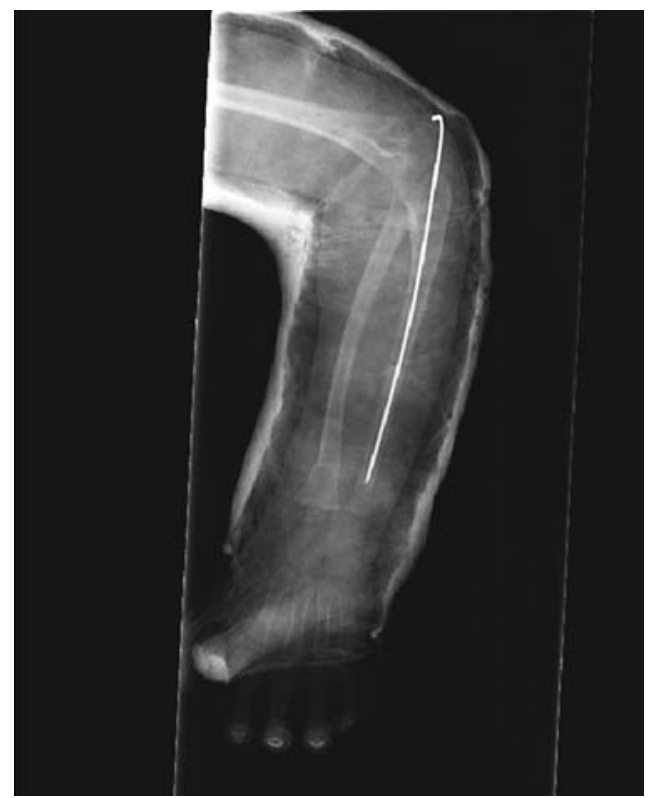

Fig. 1b

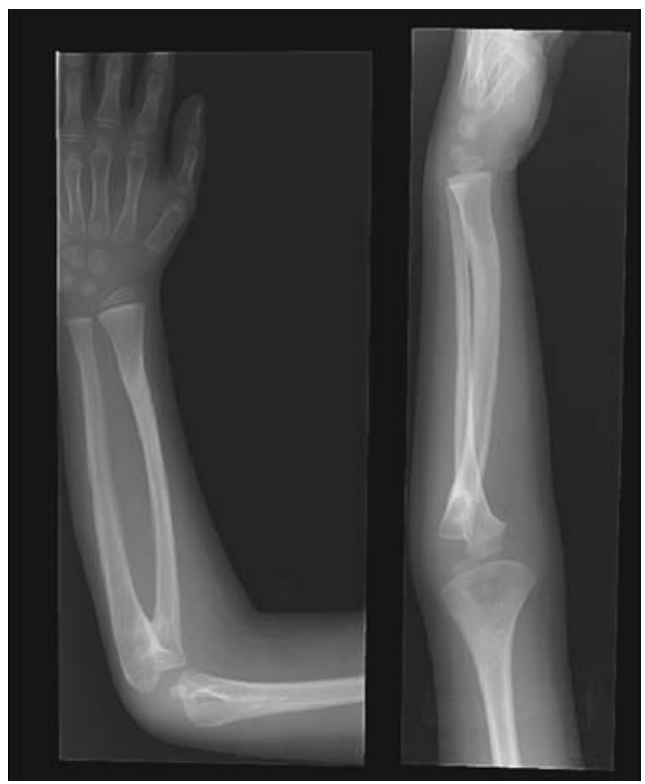

Fig. 1d

Serial radiographs of case 4 a) prior to operation, b) immediately post-operatively, c) at six weeks showing marked dorsal angulation and d) showing remodelling to nearly normal by 18 months.

resultant bridge may be fibrous or bony. ${ }^{2,11}$ The condition can lead to significant disability, especially if there is hyperpronation or when it is bilateral, as occurs in $50 \%$ to $80 \%$ of cases. ${ }^{4,9}$ In this series, the mean fixed pronation was $68^{\circ}$ and two patients had bilateral involvement.

The aetiology is unknown but a genetic basis has been suggested through the association with a positive family history and disorders such as the Apert and Klinefelter syndromes. ${ }^{1,5}$ To our knowledge there have been no previous reports of congenital radioulnar synostosis and duplication anomalies of chromosome 14 as in case 1 . Skeletal anomalies associated with congenital radioulnar synostosis include talipes equinovarus, an absent thumb, coalescence of the carpal bones, symphalangism and bowing of the radial shaft, ${ }^{5}$ which was the only associated skeletal anomaly seen in our series (case 3).

Many authors consider the synostosis as either type 1, a true bony fusion in which the radius and ulna are smoothly joined proximally for a variable distance, or type 2 in which there is congenital dislocation of the radial head with the 
synostosis just distal to the proximal radial epiphysis. ${ }^{4,6,11}$ Cleary and $\mathrm{Omer}^{2}$ described four radiographic types: I, fibrous union with a normally-located radial head; II, osseous synostosis with a normal radius; III, osseous synostosis with posterior dislocation of a hypoplastic radial head; IV, a short osseous synostosis with an anterior dislocation of the radial head. They found, as we did, that type III was the most common and this has also been noted by others. $^{8,12}$ Since there is little functional difference among the types described and the appearances may change with time, these classifications may have little clinical value. ${ }^{2,13}$

The need for operation depends on the severity of the deformity and disability. Simmons et $\mathrm{al}^{5}$ found that pronation of $60^{\circ}$ was a definite indication for osteotomy, while pronation of $15^{\circ}$ to $60^{\circ}$ was a relative indication based on the needs of the individual. Ogino and Hikino ${ }^{3}$ considered that the mean pronation of patients who complained of disability was $60^{\circ}$ and of patients without complaints $20^{\circ}$. Surgery is usually tailored to individual needs. In our series, all patients had a significant disability, with a mean pronation deformity of $68^{\circ}$.

Various techniques have been used to achieve rotation of the forearm. ${ }^{9}$ The early results of operation at the site of the synostosis were disappointing. Even after radical resection of the synostosis with interposition of fascia, fat, muscle, or extraneous materials such as plexiglass, marked restriction of movement usually recurs. ${ }^{10,13}$ As derotation takes place over a narrow segment, tightness of the soft tissue may cause loss of correction, circulatory compromise, compartment syndrome and posterior interosseous nerve palsy. ${ }^{5,14}$ The early results using free vascularised fasciofat grafts after mobilisation of the synostosis with corrective osteotomy of the radius, appear more promising, with a reported increase in the arc of rotation to between $40^{\circ}$ and $83^{\circ}$ of pronation and supination, and no associated neurovascular complications. ${ }^{12}$

Kelikian and Doumanian ${ }^{15}$ described good results in four cases of post-traumatic radioulnar synostosis, using a cylindrical steel prosthesis in two of their four cases. However, Tachdjian ${ }^{16}$ noted disappointing results with the same prosthesis in patients with a congenital synostosis. Other methods of achieving derotation while minimising the risk of neurovascular complications include the Ilizarov technique, ${ }^{17}$ correction involving initial osteotomies followed by derotation ten days later ${ }^{18,19}$ and shortening of the forearm by resecting bone from the synostosis. ${ }^{3}$

Osteotomies to position the forearm in a more functional position are an alternative to resection of the synostosis. Murase et $\mathrm{al}^{8}$ described osteotomies in the distal third of the radius and the proximal third of the ulna, held by intramedullary K-wires, in four patients with a mean age of 3.9 years, all with forearms fixed in over $70^{\circ}$ of pronation. They achieved a mean of $65^{\circ}$ of correction, with the only complication being a $20^{\circ}$ loss of correction during immobilisation in a cast. Bony union was seen at a mean of 7.5 weeks, when the wires were removed in clinic. No neurovascular complications were seen.
Our technique is similar in that the osteotomies are performed via simple surgical approaches. We used a $1.8-\mathrm{mm}$ Ilizarov wire in the ulna. The displaced distal radial osteotomy does not require fixation and any deformity remodels well with time (case 4).

There was one major complication in our series when a combination of haematoma, bony displacement and inadequate release of the deep fascia mimicked a compartment syndrome (case 3). This patient also had ipsilateral bowing of the radius, which may have exacerbated the soft-tissue compromise following derotation even if adequate fascial release had been performed.

The best position of the forearm after derotation has not been established. Green and Mital $^{9}$ suggested that in bilateral cases the best position was in $30^{\circ}$ to $45^{\circ}$ of pronation in the dominant forearm and in $20^{\circ}$ to $35^{\circ}$ of supination in the non-dominant. In unilateral cases, the ideal position was $10^{\circ}$ to $20^{\circ}$ of supination. Other authors have advocated $0^{\circ}$ to $20^{\circ}$ of supination in the non-dominant forearm and $0^{\circ}$ to $20^{\circ}$ of pronation in the dominant forearm. ${ }^{3,8,19}$ We prefer a position of $10^{\circ}$ supination in all cases as compensatory movements at the shoulder and wrist allow the forearm to be located ideally for most daily activities. All our patients were pleased with the final position of their forearms. Although hypermobility of the wrist was subjectively noted in all our patients, it was not formally measured and so may have confounded the outcome. Objective measurements of rotation however were taken at the distal radius and ulna and therefore the hypermobility should not have affected our results.

This study was limited in being retrospective with data retrieved from a review of medical notes. We were unable to formally test pre- and post-operative function in our patients by objective measures, such as the hand-function test of Jebsen et al. ${ }^{20}$

The principal advantages of this method are the ease of the surgical approach, no loss of rotational correction during follow-up and the need for stabilisation of the ulna only.

No benefits in any form have been received or will be received from a commercial party related directly or indirectly to the subject of this article.

\section{References}

1. Dawson HGW. A congenital deformity of the forearm and its operative treatment. Br Med J 1912:2:833-5.

2. Cleary JE, Omer GE. Congenital proximal radio-ulnar synostosis: natural history and functional assessment. J Bone Joint Surg [Am] 1985;67-A:539-45.

3. Ogino $\mathbf{T}$, Hikino $\mathrm{K}$. Congenital radio-ulnar synostosis compensatory rotation around the wrist and rotation osteotomy. J Hand Surg [Br] 1987;12:173-8.

4. Hansen $\mathbf{O H}$, Andersen NO. Congenital radioulnar synostosis: report of 37 cases. Acta Orthop Scand 1970;41:225-30.

5. Simmons BP, Southmayd WW, Riseborough EJ. Congenital radioulnar synostosis. J Hand Surg 1983;8:829-38.

6. Wilkie DPD. Congenital radio-ulnar synostosis. Br J Surg 1914;1:366-75.

7. Johnson LL, Mendveld SR. Congenital radio-ulnar synostosis: a classification description of the pathologic anatomy and presentation of a new surgical procedure. J Bone Joint Surg [Am] 1974;56-A:1311.

8. Murase T, Tada K, Yoshida T, Moritomo H. Derotational osteotomy at the shafts of the radius and ulna for congenital radioulnar synostosis. J Hand Surg [Am]2003;28: 133-7. 
9. Green WT, Mital MA. Congenital radioulnar synostosis: surgical treatment. J Bone Joint Surg [Am] 1979;61-A:738-43.

10. Sachar K, Akelman E, Ehrlich MG. Radioulnar synostosis. Hand Clin 1994:8: 399-404.

11. Mital MA. Congenital radioulnar synostosis and congenital dislocation of the radial head. Orthop Clin North Am 1976;7:375-83.

12. Kanaya F, Ibaraki K. Mobilization of a congenital proximal radioulnar synostosis with use of a free vascularized fascio-fat graft. J Bone Joint Surg [Am] 1998;80-A: 1186-92.

13. Miura T, Nakamura R, Suzuki M, Kanie J. Congenital radio-ulnar synostosis. $J$ Hand Surg [Br] 1984;9:153-5.

14. Hankin FM, Smith PA, Kling TF, Louis DS. Ulnar nerve palsy following rotational osteotomy of congenital radioulnar synostosis. J Pediatr Orthop 1987;7:103-6.
15. Kelikian H, Doumanian N. Swivel for proximal radio-ulnar synostosis. J Bone Joint Surg [Am] 1957;39-A:945-52.

16. Tachdjian MP. Pediatric orthopaedics. Second ed. Philadelphia: W. B. Saunders Co., 1990:180-4.

17. Bolano LE. Congenital proximal radioulnar synostosis: treatment with the llizarov method. J Hand Surg [Am] 1994;19:977-8.

18. Manske PR, McCarroll HR Jr, Hale R. Biceps tendon rerouting and percutaneous osteoclasis in the treatment of supination deformity in obstetrical palsy. J Hand Surg [Am] 1980;5:153-9.

19. Lin HH, Strecker WB, Manske PR, Schnoecker PL, Seyer DM. A surgical technique of radioulnar osteoclasis to correct severe forearm rotation deformities. J Pediatr Orthop 1995;15:53-8.

20. Jebsen RH, Taylor N, Trieschmann RB, Trotter MJ, Howard LA. An objective and standardized test of hand function. Arch Phys Med Rehab 1969;50:311-19. 